\title{
Genetic variability in Melipona scutellaris from Recôncavo, Bahia, Brazil
}

\author{
J.L. Viana ${ }^{1}$, A.K. Francisco ${ }^{1}$, C.A.L. Carvalho ${ }^{2}$ and A.M. Waldschmidt ${ }^{1}$ \\ ${ }^{1}$ Departamento de Ciências Biológicas, \\ Universidade Estadual do Sudoeste da Bahia, UESB, Jequié, BA, Brasil \\ ${ }^{2}$ Universidade Federal do Recôncavo da Bahia, Centro de Ciências Agrárias, \\ Ambientais e Biológicas, Cruz das Almas, BA, Brasil \\ Corresponding author: A.K. Francisco \\ E-mail: karinabrotas@yahoo.com.br
}

Genet. Mol. Res. 12 (3): 3444-3454 (2013)

Received January 5, 2013

Accepted May 27, 2013

Published September 10, 2013

DOI http://dx.doi.org/10.4238/2013.September.10.1

\begin{abstract}
Bees play a key role in pollination and thereby help maintain plant diversity. The stingless bee Melipona scutellaris is an important pollinator in northeastern Brazil because it is endemic to this region. Both deforestation and timber harvesting have reduced the nesting sites for this species, thus reducing its population and range. Genetic studies may help reverse this process by providing important tools for their proper management with a view to conservation of this species. Microsatellite markers have proven to be ideal for mapping genes and population genetic studies. Our aim was to study, using microsatellite markers, the interpopulation genetic variability of $M$. scutellaris in different parts of the Recôncavo region in Bahia State, Brazil. In all, 95 adult workers from 11 localities in Recôncavo Baiano (Amargosa, Cabaceiras do Paraguaçu, Conceição da Feira, Conceição do Almeida, Domingos Macedo Costa, Governador Mangabeira, Jaguaripe, Jiquiriça, Maragojipe, São Felipe, and Vera Cruz) were analyzed using 10 pairs of microsatellite primers developed for different Meliponini species. The total number of alleles, allele richness, and genetic diversity ranged from 2 to 7 per locus (average $=4.4$ ), 1.00 to 4.88 , and 0.0 to 0.850 , respectively. The expected and observed
\end{abstract}


heterozygosities varied from 0.0 to 0.76 and 0.0 to 0.84 , respectively. No locus showed deviation from the expected frequencies in the chisquare test or linkage disequilibrium. The fixation index, analysis of molecular variance, and unweighted pair-group method using the arithmetic average revealed the effects of human activities on the populations of M. scutellaris, as little genetic structure was detected.

Key words: Recôncavo Baiano; Meliponini tribe; Pollinators; Microsatellite markers; Genetic diversity; Conservation

\section{INTRODUCTION}

Within stingless bees, the species Melipona scutellaris, popularly known as "uruçu verdadeira", "uruçu do nordeste", or "uruçu do campo", stands out for being endemic to northeastern Brazil. Its range comprises the area from Bahia to Rio Grande do Norte States, particularly transition zones between the Atlantic Forest and caatinga (semi-arid region). $M$. scutellaris is one of the most raised species for honey and propolis production, representing an important income in familial agriculture (Kerr et al., 1996).

Deforestation and timber harvesting have been destroying the nesting sites of stingless bees (cavities in trees or soil), while agrochemicals affect colonies or visiting flowers in addition to contaminating rivers and ponds in which the bees collect water. These activities have effectively reduced their population size and, consequently, their geographical range. Population reduction eventually leads to the loss of genetic variability. In bees, this process is particularly damaging once the lack of genetic variation interferes with sex determination, potentially increasing the formation of diploid males. Therefore, genetic studies might be helpful to counteract this process by providing relevant information to design proper management techniques focused on the conservation of bee species (Carvalho-Zilse and Kerr, 2006).

The region named Recôncavo Baiano encompasses an area of $5250.51 \mathrm{~km}^{2}$ in Bahia State with a human population of 576,672 inhabitants, according to the Brazilian Institute of Geography and Statistics. This region includes an intricate landscape that includes coastal zones with several river basins, waterfalls, beaches, and mangroves, and a few relicts of the Atlantic forest. Indeed, most of the Atlantic forest, one of the largest original biomes in Brazil, has been intensively deforested and replaced by sugarcane plantations, pastures for cattle, and other crops that, coupled with an inefficient recovery policy, determined the maintenance of a few forest patches (Oliveira and Albuquerque, 2010).

Therefore, the aim of this study was to estimate the interpopulation genetic variation of M. scutellaris from Recôncavo Baiano based on microsatellite markers in order to understand the effects of environmental changes in this region on the population of this important and intensively raised pollinator in northeastern Brazil.

\section{MATERIAL AND METHODS}

The samples comprised adult workers of $M$. scutellaris obtained from bee keepers or from nests collected in the forests. Specimens from 95 colonies from 11 localities in Recôncavo Baiano [Amargosa (AM), Cabaceiras do Paraguaçu (CBP), Conceição da Feira 
(CF), Conceição do Almeida (CA), Domingos Macedo Costa (DMC), Governador de Mangabeira (GOV), Jaguaripe (JG), Jiquiriça (JQ), Maragojipe (MGJ), São Felipe (SF), Vera Cruz (VC)] (Table 1 and Figure 1) were used. DNA extraction was performed according to Waldschmidt et al. (1997) using 1 worker per colony.

Table 1. Localities, number of colonies, altitude of samples, and geographic coordinates of Melipona scutellaris used in this study.

\begin{tabular}{|c|c|c|c|c|}
\hline Municipality & Code & No. of colonies & Altitude (m) & Geographic coordinates \\
\hline Amargosa & $\mathrm{AM}$ & 13 & 400 & $\begin{array}{l}12^{\circ} 48^{\prime} 03.9^{\prime \prime S} \\
39^{\circ} 07^{\prime} 34.1^{\prime \prime} \mathrm{W}\end{array}$ \\
\hline Cabaceiras do Paraguaçu & CBP & 5 & 210 & $\begin{array}{l}12^{\circ} 32^{\prime} 08^{\prime \prime S} \\
39^{\circ} 11^{\prime} 27^{\prime \prime} \mathrm{W}\end{array}$ \\
\hline Conceição da Feira & $\mathrm{CF}$ & 4 & 227 & $\begin{array}{l}12^{\circ} 39^{\prime} 20^{\prime \prime} \mathrm{S} \\
39^{\circ} 06^{\prime} 10^{\prime \prime} \mathrm{W}\end{array}$ \\
\hline Conceição do Almeida & $\mathrm{CA}$ & 10 & 216 & $\begin{array}{l}12^{\circ} 48^{\prime} 3.9^{\prime \prime S} \\
39^{\circ} 07^{\prime} 34.11^{\prime W}\end{array}$ \\
\hline Domingos Macedo Costa & DMC & 5 & 192 & $\begin{array}{l}12^{\circ} 51^{\prime} 31.3 \mathrm{~s} \mathrm{~S} \\
39^{\circ} 09^{\prime} 28.4^{\prime \prime \mathrm{W}}\end{array}$ \\
\hline Governador Mangabeira & GOV & 11 & 204 & $\begin{array}{l}12^{\circ} 34^{\prime} 51.2^{\prime \prime S} \\
39^{\circ} 06^{\prime} 51.6^{\prime \prime} \mathrm{W}\end{array}$ \\
\hline Jaguaripe & JG & 13 & 11 & $\begin{array}{l}13^{\circ} 06^{\prime} 31.0^{\prime \prime S} \\
39^{\circ} 07^{\prime} 56,3^{\prime \prime} \mathrm{W}\end{array}$ \\
\hline Jiquiriça & JQ & 6 & 342 & $\begin{array}{l}13^{\circ} 15^{\prime} 24^{\prime \prime S} \\
39^{\circ} 34^{\prime} 20^{\prime \prime} \mathrm{W}\end{array}$ \\
\hline Maragojipe & MGJ & 11 & 39 & $\begin{array}{l}12^{\circ} 50^{\prime} 16^{\prime \prime} \mathrm{S} \\
38^{\circ} 54^{\prime} 51.8^{\prime \prime} \mathrm{W}\end{array}$ \\
\hline São Felipe & $\mathrm{SF}$ & 4 & 195 & $\begin{array}{l}12^{\circ} 45^{\prime} 39^{\prime \prime} \mathrm{S} \\
39^{\circ} 03^{\prime} 02.9^{\prime \prime} \mathrm{W}\end{array}$ \\
\hline Vera Cruz & $\mathrm{VC}$ & 13 & 13 & $\begin{array}{l}12^{\circ} 57^{\prime} 37 " \mathrm{~S} \\
38^{\circ} 36^{\prime} 31 " \mathrm{~W}\end{array}$ \\
\hline
\end{tabular}

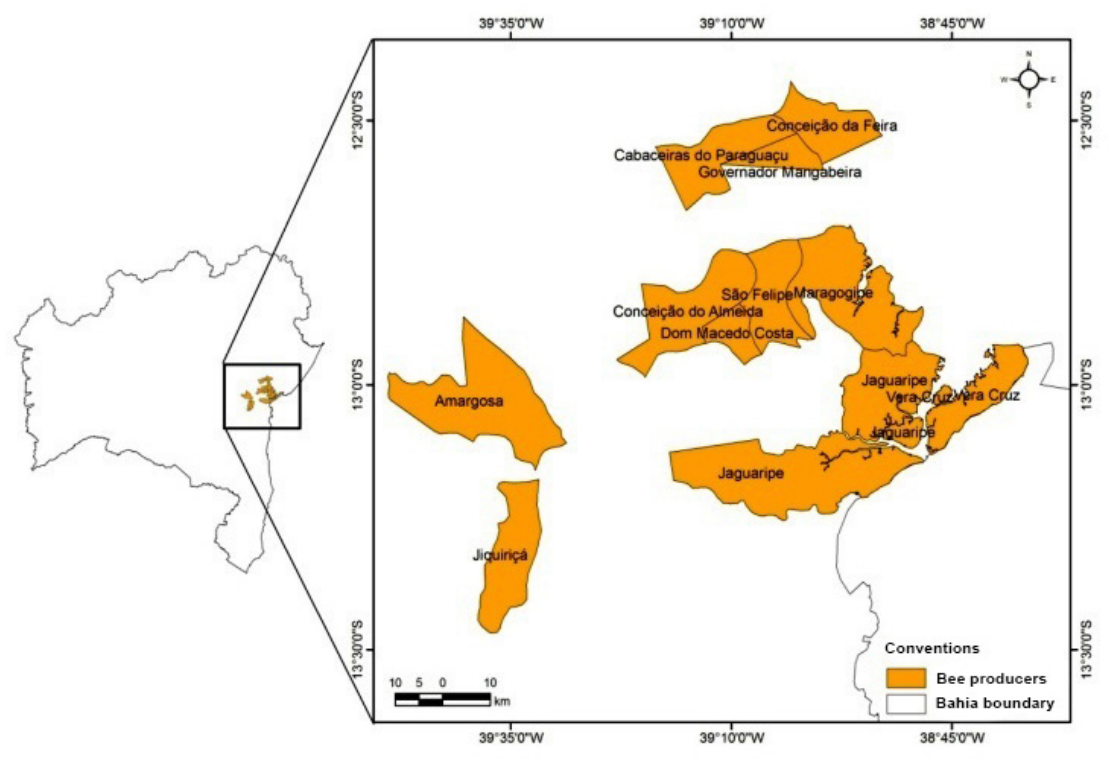

Figure 1. Map of Recôncavo Baiano, Bahia, showing the sampled localities of Melipona scutellaris. 
Ten heterologous microsatellite primers (Table 2) were selected and amplified as described by Peters et al. (1998). The amplifications were performed in a total volume of $10 \mu \mathrm{L}$ containing $1 \mathrm{X}$ buffer (Biotools, Spain), $0.1 \mathrm{mM}$ of each dNTP, $0.4 \mu \mathrm{M}$ of each primer, $1.5 \mathrm{mM} \mathrm{MgCl}_{2}, 0.5 \mathrm{U}$ Taq polymerase (Biotools), and $20 \mathrm{ng}$ template DNA. The PCR conditions were as follows: an initial denaturation step at $94^{\circ} \mathrm{C}$ for $3 \mathrm{~min}$, followed by 39 cycles at $92^{\circ} \mathrm{C}$ for $30 \mathrm{~s}$, specific annealing temperature of each primer for $1 \mathrm{~min}$, and $72^{\circ} \mathrm{C}$ for $30 \mathrm{~s}$, plus a final extension step at $72^{\circ} \mathrm{C}$ for $5 \mathrm{~min}$. The PCRs were carried out in an ATC201 thermocycler (Nyx Technik, USA). The amplification products were run using electrophoresis on an $8 \%$ non-denaturing polyacrylamide gel, visualized by $0.2 \%$ silver nitrate staining, and photodocumented.

\begin{tabular}{|c|c|c|c|c|c|}
\hline Locus & Size & Repeat & $\mathrm{Ta}^{1}\left({ }^{\circ} \mathrm{C}\right)$ & $\mathrm{Ta}^{2}\left({ }^{\circ} \mathrm{C}\right)$ & Primer sequence $\left(5^{\prime}-3^{\prime}\right)$ \\
\hline Mbi215 & 92 & $(\mathrm{TTC})_{6}$ & 57.5 & 60.0 & $\begin{array}{l}\text { F: AGAGACGAAAAGTGGCGG } \\
\text { R: GCTGTTTCCCTGTTCGAG }\end{array}$ \\
\hline Mbi218 & 131 & $(\mathrm{CCT})_{3}(\mathrm{TCT})_{7}$ & 60.0 & 60.0 & $\begin{array}{l}\text { F: CTCGACTTAATTTCCATCGGC } \\
\text { R: GCAATTTCAATCGCGACC }\end{array}$ \\
\hline Mbi232 & 128 & $(\mathrm{CTT})_{13}$ & 50.0 & 53.0 & $\begin{array}{l}\text { F: TTTTTCTCTTAAATTTTCTTCT } \\
\text { R: CTTACTCGACGACTTTATTT }\end{array}$ \\
\hline Mbi233 & 119 & $(\mathrm{GAA})_{15}$ & 57.5 & 53.0 & $\begin{array}{l}\text { F: ACGAGCACGGGCCATAA } \\
\text { R: GATCCATCGACCGCTTCTT }\end{array}$ \\
\hline Mbi254 & 213 & $(\mathrm{AAG})_{11}$ & 55.0 & 53.0 & $\begin{array}{l}\text { F: CAATCGTTGGAAGGGAAC } \\
\text { R: GGACCTATACCCAAGTCCAT }\end{array}$ \\
\hline Mbi256 & 127 & $(\mathrm{AGA})_{9}$ & 57.5 & 53.0 & $\begin{array}{l}\text { F: GGATTCAAGCAGACGATA } \\
\text { R: GATCAAAGTCCCCATCTT }\end{array}$ \\
\hline Mmo15 & 100 & $(\mathrm{GAAC})_{5}$ & 54.0 & 53.0 & $\begin{array}{l}\text { F: GCAAAATGAGCAAACGGACA } \\
\text { R: GAGAGAGAGGGAGGTTC }\end{array}$ \\
\hline Mru03 & 120 & $(\mathrm{AG})_{6}(\mathrm{CGTT})_{6}$ & 63.0 & 57.0 & $\begin{array}{l}\text { F: AGAGAGAGAGAGAGACGC } \\
\text { R: GGTTGAAAGGAGAACGAAC }\end{array}$ \\
\hline Mru14 & 136 & $(\mathrm{TCG})_{8} \mathrm{TT}(\mathrm{GTC})_{4}$ & 62.5 & 58.0 & $\begin{array}{l}\text { F: GCTGTTTCCCTGTTCGAG } \\
\text { R: CCCCTATCTTTTATGCCG }\end{array}$ \\
\hline Tc4.287 & 179 & $(\mathrm{GAA})_{9}$ & 55.0 & 53.0 & $\begin{array}{l}\text { F: TCCACCGCGATACGATGGTAC } \\
\text { R: GTAATACAACGCGGCTTCCTC }\end{array}$ \\
\hline
\end{tabular}

$\mathrm{Ta}^{1}\left({ }^{\circ} \mathrm{C}\right)=$ annealing temperature. $\operatorname{Ta}^{2}\left({ }^{\circ} \mathrm{C}\right)=$ optimized annealing temperature.

The diversity estimators, i.e., number of alleles per locus, allele richness (Petit et al., 1998), and genetic diversity (Nei, 1978), were calculated using the FSTAT software (Goudet, 1995). Analyses of observed heterozygosity $\left(H_{\mathrm{O}}\right)$ and expected heterozygosity $\left(H_{\mathrm{E}}\right)(\mathrm{Nei}$, 1978) per locus in each population were performed using the TFPGA software version 1.3 (Miller, 1997).

The GENEPOP 4.0 software (Raymond and Rousset, 1995) was used to estimate the deviation of microsatellite loci from Hardy-Weinberg equilibrium (HWE) using the chisquare test and to verify linkage disequilibrium (LD) between the loci. The FreeNA program (Chapuis and Estoup, 2007) was used to generate a corrected dataset of null alleles that might influence the values of genetic differentiation. The estimated values in the chi-square test were adjusted by the sequential Bonferroni's correction $\mathrm{P} \leq 0.05$ (Rice, 1989). 
Analysis of molecular variance (AMOVA) was used to verify the genetic structure within and among populations. The fixation index $F_{\text {ST }}$ (Weir and Cockerham, 1984) was used to estimate the pairwise genetic distance between localities. These analyses were performed using the Arlequin 3.01 software (Excoffier et al., 2005). Grouping analysis was carried out with the unweighted pair-group method using the arithmetic average (UPGMA) (Dias, 1998) in the TFPGA software version 1.3 (Miller, 1997).

The Structure 2.1 software (Pritchard et al., 2000) was used to identify the population structure based on individual genotypes. Models with K from 1 to 10 populations, replicated 10 times, were tested assuming "admixture" and "correlated allele frequencies". These tests were performed via Markov-Monte Carlo Chains, with a burn-in of 500,000 and 1,000,000 replicates. The $\mathrm{K}$ values were verified using the Harvester software (Earl and vonHoldt, 2012).

\section{RESULTS}

The total number of alleles in all loci was equal to 44, ranging from 20 in SF to 38 in AM, with a mean value of 29.36 alleles per locality. The number of alleles, allele richness, and genetic diversity within each locus are shown in Table 3. In those localities with genetic diversity equal to zero, the loci were monomorphic. Both $H_{\mathrm{E}}$ and $H_{\mathrm{O}}$ are listed in Table 4.

No loci deviated from the expected frequencies. However, the HWE could not be estimated for loci Mbi215 in VC, Mru03 in CBP, CF, GOV, and SF, Mru14 in CF, Mmo15 in CF, DMC, JG, JQ, MGJ, SF, and VC, and Tc4.287 in CBP, CF, DMC, JQ, MGJ, SF, and $\mathrm{VC}$, once these loci were monomorphic in these localities. The $\mathrm{P}$ values in relation to HWE are listed in Table 4. In relation to LD, only locus Mru03 Tc4.287 was found in LD after sequential Bonferroni's correction $\mathrm{P} \leq 0.05$ (Rice, 1989) (Table 5).

The pairwise values for the $F_{\mathrm{ST}}$ were low, ranging from -0.01 between $\mathrm{AM}$ and $\mathrm{DMC}$ and between CA and DMC to 0.23 between JQ and MGJ. Moreover, the $F_{\mathrm{ST}}$ values were significant in all comparisons using the GOV locality in most of the comparisons involving JQ, MGJ, SF, and VC (9 of 10 comparisons) and in some of the comparisons encompassing AM, CBP, CA (6 of 10), and CF (4 of 10) (Table 6). The total $F_{\mathrm{ST}}$ value in all populations and all loci was low, but positive $\left(F_{\mathrm{ST}}\right.$ total $\left.=0.10\right)$ (Table 7). Likewise AMOVA revealed that $89.33 \%$ of the total genetic variation in $M$. scutellaris was found within localities (Table 7).

Grouping analysis via UPGMA (Figure 2) based on the mean values of genetic distances between colonies showed the occurrence of 4 clusters. The first group comprised the populations from DMC, VC, CA, AM, CBP, CF, JG, and SF, the second group was composed of samples from MGJ, and the 3rd and 4th groups were exclusively formed by GOV and JQ samples. Nonetheless, the bootstrap values were inconsistent. Analyses using Structure revealed a single group (Figure 3), although the $\mathrm{K}$ value determined using Harvester was $\mathrm{K}=10$ (Figure 4). 
Genetic variability in Melipona scutellaris from Recôncavo

Table 3. Number of individuals analyzed $(\mathrm{N})$, number of alleles $\left(N_{\mathrm{A}}\right)$, number of private alleles $(\mathrm{Pa})$, allele richness (Ar), and Nei's genetic diversity (Nd) obtained in Melipona scutellaris per locus in each locality.

\begin{tabular}{|c|c|c|c|c|c|c|c|c|c|c|c|}
\hline & $\mathrm{AM}$ & CBP & $\mathrm{CF}$ & $\mathrm{CA}$ & DMC & GOV & JG & JQ & MGJ & SF & $\mathrm{VC}$ \\
\hline \multicolumn{12}{|l|}{ Mbi215 } \\
\hline $\mathrm{N}$ & 13 & 5 & 4 & 10 & 5 & 11 & 13 & 6 & 11 & 4 & 13 \\
\hline$N_{\mathrm{t}}$ & 4 & 3 & 3 & 4 & 3 & 3 & 4 & 3 & 2 & 2 & 2 \\
\hline $\mathrm{Pa}$ & 0 & 0 & 0 & 0 & 0 & 1 & 0 & 0 & 0 & 0 & 0 \\
\hline $\mathrm{Ar}$ & 3.05 & 2.80 & 3.00 & 3.42 & 2.60 & 2.29 & 2.76 & 2.58 & 1.86 & 2.00 & 1.31 \\
\hline $\mathrm{Nd}$ & 0.62 & 0.60 & 0.58 & 0.67 & 0.38 & 0.43 & 0.53 & 0.43 & 0.31 & 0.50 & 0.08 \\
\hline \multicolumn{12}{|l|}{ Mbi218 } \\
\hline $\mathrm{N}$ & 13 & 5 & 4 & 10 & 5 & 11 & 13 & 6 & 11 & 4 & 13 \\
\hline$N_{\mathrm{A}}$ & 2 & 2 & 2 & 2 & 2 & 3 & 3 & 3 & 3 & 2 & 2 \\
\hline $\mathrm{Pa}$ & 0 & 0 & 0 & 0 & 0 & 0 & 0 & 0 & 0 & 0 & 0 \\
\hline $\mathrm{Ar}$ & 1.87 & 2.00 & 2.00 & 1.98 & 1.98 & 2.47 & 2.40 & 2.67 & 2.23 & 2.00 & 2.00 \\
\hline $\mathrm{Nd}$ & 0.32 & 0.55 & 0.42 & 0.44 & 0.35 & 0.45 & 0.44 & 0.60 & 0.39 & 0.58 & 0.51 \\
\hline \multicolumn{12}{|l|}{ Mbi232 } \\
\hline $\mathrm{N}$ & 13 & 5 & 4 & 10 & 5 & 11 & 13 & 6 & 11 & 4 & 13 \\
\hline$N_{\mathrm{A}}$ & 6 & 3 & 3 & 5 & 5 & 4 & 4 & 5 & 3 & 4 & 4 \\
\hline $\mathrm{Pa}$ & 0 & 0 & 0 & 0 & 0 & 0 & 0 & 0 & 0 & 0 & 0 \\
\hline $\mathrm{Ar}$ & 4.25 & 2.98 & 3.00 & 3.40 & 4.56 & 3.15 & 2.81 & 4.52 & 2.84 & 4.00 & 3.39 \\
\hline $\mathrm{Nd}$ & 0.80 & 0.68 & 0.71 & 0.66 & 0.83 & 0.64 & 0.59 & 0.85 & 0.65 & 0.75 & 0.67 \\
\hline \multicolumn{12}{|l|}{ Mbi233 } \\
\hline $\mathrm{N}$ & 13 & 5 & 4 & 10 & 5 & 11 & 13 & 6 & 11 & 4 & 13 \\
\hline$N$ & 6 & 4 & 4 & 6 & 5 & 3 & 5 & 6 & 6 & 3 & 5 \\
\hline $\mathrm{Pa}$ & 0 & 0 & 0 & 0 & 0 & 0 & 0 & 0 & 0 & 0 & 0 \\
\hline $\mathrm{Ar}$ & 3.86 & 3.40 & 4.00 & 4.59 & 4.58 & 2.85 & 3.67 & 4.89 & 4.12 & 3.00 & 4.16 \\
\hline $\mathrm{Nd}$ & 0.74 & 0.53 & 0.75 & 0.83 & 0.83 & 0.66 & 0.73 & 0.85 & 0.75 & 0.75 & 0.80 \\
\hline \multicolumn{12}{|l|}{ Mbi254 } \\
\hline $\mathrm{N}$ & 13 & 5 & 4 & 10 & 5 & 11 & 13 & 6 & 11 & 4 & 13 \\
\hline$N_{\mathrm{A}}$ & 5 & 3 & 4 & 3 & 4 & 3 & 4 & 4 & 3 & 2 & 3 \\
\hline $\mathrm{Pa}$ & 0 & 0 & 0 & 0 & 0 & 0 & 0 & 0 & 0 & 0 & 0 \\
\hline $\mathrm{Ar}$ & 3.55 & 2.60 & 4.00 & 2.61 & 3.78 & 2.13 & 3.56 & 3.32 & 2.92 & 2.00 & 2.26 \\
\hline $\mathrm{Nd}$ & 0.67 & 0.40 & 0.75 & 0.48 & 0.80 & 0.32 & 0.75 & 0.63 & 0.67 & 0.50 & 0.46 \\
\hline \multicolumn{12}{|l|}{ Mbi256 } \\
\hline $\mathrm{N}$ & 13 & 5 & 4 & 10 & 5 & 11 & 13 & 6 & 11 & 4 & 13 \\
\hline$N_{\mathrm{A}}$ & 3 & 2 & 2 & 3 & 2 & 2 & 3 & 2 & 2 & 2 & 2 \\
\hline $\mathrm{Pa}$ & 0 & 0 & 0 & 0 & 0 & 0 & 0 & 0 & 0 & 0 & 0 \\
\hline $\mathrm{Ar}$ & 2.29 & 2.00 & 2.00 & 2.87 & 2.00 & 2.00 & 2.82 & 2.00 & 1.98 & 2.00 & 1.99 \\
\hline $\mathrm{Nd}$ & 0.52 & 0.50 & 0.50 & 0.66 & 0.55 & 0.49 & 0.63 & 0.47 & 0.46 & 0.42 & 0.48 \\
\hline \multicolumn{12}{|l|}{ Mru03 } \\
\hline $\mathrm{N}$ & 13 & 5 & 4 & 10 & 5 & 11 & 13 & 6 & 11 & 4 & 13 \\
\hline$N_{A}$ & 4 & 2 & 2 & 3 & 3 & 2 & 4 & 4 & 4 & 1 & 3 \\
\hline $\mathrm{Pa}$ & 0 & 0 & 0 & 0 & 0 & 0 & 0 & 0 & 0 & 0 & 0 \\
\hline $\mathrm{Ar}$ & 3.19 & 1.80 & 2.00 & 2.46 & 2.80 & 1.36 & 2.15 & 3.32 & 2.93 & 1.00 & 2.40 \\
\hline $\mathrm{Nd}$ & 0.62 & 0.20 & 0.25 & 0.43 & 0.60 & 0.09 & 0.29 & 0.63 & 0.60 & 0.00 & 0.44 \\
\hline \multicolumn{12}{|l|}{ Mru14 } \\
\hline $\mathrm{N}$ & 13 & 5 & 4 & 10 & 5 & 11 & 13 & 6 & 11 & 4 & 13 \\
\hline$N$ & 4 & 2 & 2 & 3 & 4 & 4 & 4 & 3 & 4 & 2 & 4 \\
\hline $\mathrm{Pa}$ & 0 & 0 & 0 & 0 & 0 & 0 & 0 & 0 & 0 & 0 & 0 \\
\hline $\mathrm{Ar}$ & 3.10 & 2.00 & 2.00 & 2.89 & 3.78 & 3.39 & 3.16 & 2.82 & 2.96 & 2.00 & 3.41 \\
\hline Nd & 0.64 & 0.45 & 0.25 & 0.67 & 0.80 & 0.66 & 0.69 & 0.55 & 0.65 & 0.50 & 0.72 \\
\hline \multicolumn{12}{|l|}{ Mmo15 } \\
\hline $\mathrm{N}$ & 13 & 5 & 4 & 10 & 5 & 11 & 13 & 6 & 11 & 4 & 13 \\
\hline$N_{4}$ & 2 & 2 & 1 & 2 & 1 & 2 & 1 & 1 & 1 & 1 & 1 \\
\hline $\mathrm{Pa}$ & 0 & 0 & 0 & 0 & 0 & 0 & 0 & 0 & 0 & 0 & 0 \\
\hline $\mathrm{Ar}$ & 1.87 & 2.00 & 1.00 & 1.95 & 1.00 & 1.61 & 1.00 & 1.00 & 1.00 & 1.00 & 1.00 \\
\hline Nd & 0.32 & 0.45 & 0.00 & 0.39 & 0.00 & 0.17 & 0.00 & 0.00 & 0.00 & 0.00 & 0.00 \\
\hline \multicolumn{12}{|l|}{ Tc4.287 } \\
\hline $\mathrm{N}$ & 13 & 5 & 4 & 10 & 5 & 11 & 13 & 6 & 11 & 4 & 13 \\
\hline$N_{\mathrm{A}}$ & 2 & 2 & 2 & 2 & 1 & 3 & 3 & 1 & 1 & 1 & 1 \\
\hline $\mathrm{Pa}$ & 0 & 0 & 0 & 0 & 0 & 0 & 0 & 0 & 0 & 0 & 0 \\
\hline $\mathrm{Ar}$ & 1.80 & 1.80 & 2.00 & 1.65 & 1.00 & 2.86 & 2.33 & 1.00 & 1.00 & 1.00 & 1.00 \\
\hline $\mathrm{Nd}$ & 0.27 & 0.20 & 0.25 & 0.19 & 0.00 & 0.66 & 0.39 & 0.00 & 0.00 & 0.00 & 0.00 \\
\hline Total $N$ per locality & 38 & 25 & 25 & 33 & 30 & 29 & 35 & 32 & 29 & 20 & 27 \\
\hline Mean $N_{\mathrm{A}}$ per locality & 3.8 & 2.5 & 2.5 & 3.3 & 3.0 & 2.9 & 3.5 & 3.2 & 2.9 & 2.0 & 2.7 \\
\hline Mean Ar per locality & 2.88 & 2.34 & 2.50 & 2.78 & 2.81 & 2.41 & 2.66 & 2.81 & 2.38 & 2.00 & 2.29 \\
\hline Mean Nd per locality & 0.55 & 0.46 & 0.45 & 0.54 & 0.51 & 0.46 & 0.50 & 0.50 & 0.45 & 0.40 & 0.42 \\
\hline
\end{tabular}

For locality and locus abbreviations, see Tables 1 and 2, respectively. 
Table 4. Expected heterozygosity $\left(H_{\mathrm{E}}\right)$, observed heterozygosity $\left(H_{\mathrm{O}}\right)$, and probability of Hardy-Weinberg equilibrium deviation (P) in Melipona scutellaris from Recôncavo Baiano.

\begin{tabular}{|c|c|c|c|c|c|c|c|c|c|c|c|}
\hline & $\mathrm{AM}$ & CBP & $\mathrm{CF}$ & CA & DMC & GOV & JG & JQ & MGJ & SF & $\mathrm{VC}$ \\
\hline \multicolumn{12}{|l|}{$H_{\mathrm{E}}$} \\
\hline Mbi215 & 0.55 & 0.54 & 0.53 & 0.52 & 0.34 & 0.42 & 0.46 & 0.40 & 0.30 & 0.50 & 0.07 \\
\hline Mbi218 & 0.31 & 0.50 & 0.38 & 0.42 & 0.32 & 0.24 & 0.31 & 0.44 & 0.17 & 0.50 & 0.50 \\
\hline Mbi232 & 0.69 & 0.62 & 0.63 & 0.35 & 0.66 & 0.63 & 0.65 & 0.63 & 0.70 & 0.69 & 0.71 \\
\hline Mbi233 & 0.74 & 0.66 & 0.63 & 0.70 & 0.76 & 0.48 & 0.73 & 0.72 & 0.76 & 0.66 & 0.75 \\
\hline Mbi254 & 0.55 & 0.34 & 0.63 & 0.47 & 0.58 & 0.31 & 0.72 & 0.40 & 0.64 & 0.50 & 0.45 \\
\hline Mbi256 & 0.45 & 0.48 & 0.47 & 0.48 & 0.48 & 0.48 & 0.45 & 0.44 & 0.43 & 0.38 & 0.47 \\
\hline Mru03 & 0.51 & 0.18 & 0.22 & 0.26 & 0.32 & 0.09 & 0.28 & 0.40 & 0.57 & 0.00 & 0.31 \\
\hline Mru14 & 0.48 & 0.42 & 0.22 & 0.64 & 0.62 & 0.53 & 0.53 & 0.38 & 0.54 & 0.47 & 0.62 \\
\hline Mmo15 & 0.31 & 0.42 & 0.00 & 0.38 & 0.00 & 0.17 & 0.00 & 0.00 & 0.00 & 0.00 & 0.00 \\
\hline Tc4.287 & 0.26 & 0.18 & 0.22 & 0.18 & 0.00 & 0.50 & 0.20 & 0.00 & 0.00 & 0.00 & 0.00 \\
\hline \multicolumn{12}{|l|}{$H_{\mathrm{o}}$} \\
\hline Mbi215 & 0.57 & 0.60 & 0.61 & 0.54 & 0.38 & 0.44 & 0.48 & 0.44 & 0.31 & 0.57 & 0.08 \\
\hline Mbi218 & 0.32 & 0.56 & 0.43 & 0.44 & 0.36 & 0.25 & 0.32 & 0.48 & 0.17 & 0.57 & 0.52 \\
\hline Mbi232 & 0.72 & 0.69 & 0.71 & 0.36 & 0.73 & 0.66 & 0.68 & 0.68 & 0.73 & 0.79 & 0.74 \\
\hline Mbi233 & 0.77 & 0.73 & 0.71 & 0.74 & 0.84 & 0.51 & 0.76 & 0.79 & 0.80 & 0.75 & 0.78 \\
\hline Mbi254 & 0.58 & 0.38 & 0.71 & 0.49 & 0.64 & 0.32 & 0.75 & 0.44 & 0.68 & 0.57 & 0.46 \\
\hline Mbi256 & 0.47 & 0.53 & 0.54 & 0.51 & 0.53 & 0.51 & 0.47 & 0.48 & 0.45 & 0.43 & 0.49 \\
\hline Mru03 & 0.53 & 0.20 & 0.25 & 0.27 & 0.36 & 0.09 & 0.29 & 0.44 & 0.59 & 0.00 & 0.32 \\
\hline Mru14 & 0.50 & 0.47 & 0.25 & 0.67 & 0.69 & 0.55 & 0.55 & 0.41 & 0.57 & 0.54 & 0.64 \\
\hline Mmo15 & 0.32 & 0.47 & 0.00 & 0.39 & 0.00 & 0.17 & 0.00 & 0.00 & 0.00 & 0.00 & 0.00 \\
\hline Tc4.287 & 0.27 & 0.20 & 0.25 & 0.19 & 0.00 & 0.52 & 0.21 & 0.00 & 0.00 & 0.00 & 0.00 \\
\hline \multicolumn{12}{|l|}{$P$} \\
\hline Mbi215 & 0.71 & 0.63 & 1.00 & 0.28 & 1.00 & 1.00 & 0.13 & 1.00 & 1.00 & 0.31 & - \\
\hline Mbi218 & 1.00 & 1.00 & 1.00 & 1.00 & 1.00 & 0.61 & 0.66 & 1.00 & 0.20 & 1.00 & 0.60 \\
\hline Mbi232 & 0.52 & 1.00 & 1.00 & 0.49 & 0.89 & 0.69 & 1.00 & 0.88 & 0.31 & 1.00 & 0.68 \\
\hline Mbi233 & 0.46 & 1.00 & 0.32 & 0.52 & 0.84 & 0.48 & 0.83 & 0.03 & 0.86 & 0.06 & 0.77 \\
\hline Mbi254 & 0.52 & 0.11 & 0.32 & 1.00 & 0.70 & 1.00 & 0.80 & 0.77 & 0.30 & 0.31 & 0.16 \\
\hline Mbi256 & 1.00 & 0.43 & 1.00 & 0.84 & 1.00 & 0.07 & 1.00 & 1.00 & 1.00 & 1.00 & 0.08 \\
\hline Mru03 & 0.86 & - & - & 0.49 & 0.62 & - & 1.00 & 0.74 & 0.11 & - & 0.67 \\
\hline Mru14 & 0.87 & 1.00 & - & 0.22 & 0.69 & 0.71 & 0.66 & 0.51 & 0.78 & 1.00 & 0.51 \\
\hline Mmo15 & 1.00 & 1.00 & - & 1.00 & - & 1.00 & - & - & - & - & - \\
\hline Tc4.287 & 1.00 & - & - & 1.00 & - & 1.00 & 0.52 & - & - & - & - \\
\hline
\end{tabular}

$(-)=$ monomorphic loci for the sampled locality. For locality and locus abbreviations, see Tables 1 and 2, respectively.

Table 5. Results of pairwise probabilities of linkage disequilibrium considering all 10 loci in samples of Melipona scutellaris from Recôncavo Baiano.

\begin{tabular}{llll}
\hline Locus pair & Probability $(\mathrm{P})$ & Locus pair & Probability (P) \\
\hline Mbi215 and Mbi218 & 0.95 & Mbi232 and Mru14 & 0.99 \\
Mbi215 and Mbi232 & 0.97 & Mbi233 and Mru14 & 1.00 \\
Mbi218 and Mbi232 & 0.99 & Mbi254 and Mru14 & 0.99 \\
Mbi215 and Mbi233 & 0.92 & Mbi256 and Mru14 & 0.97 \\
Mbi218 and Mbi233 & 0.99 & Mru03 and Mru14 & 0.85 \\
Mbi232 and Mbi233 & 0.97 & Mbi215 and Mmo15 & 0.49 \\
Mbi215 and Mbi254 & 0.96 & Mbi218 and Mmo15 & 0.47 \\
Mbi218 and Mbi254 & 0.96 & Mbi232 and Mmo15 & 0.89 \\
Mbi232 and Mbi254 & 0.61 & Mbi254 and Mmo15 & 0.57 \\
Mbi233 and Mbi254 & 1.00 & Mbi256 and Mmo15 & 0.98 \\
Mbi215 and Mbi256 & 0.74 & Mru03 and Mmo15 & 0.99 \\
Mbi218 and Mbi256 & 0.99 & Mru14 and Mmo15 & 0.78 \\
Mbi232 and Mbi256 & 0.91 & Mbi215 and Tc4.287 & 0.66 \\
Mbi233 and Mbi256 & 1.00 & Mbi218 and Tc4.287 & 0.40 \\
Mbi254 and Mbi256 & 0.66 & Mbi232 and Tc4.287 & 0.94 \\
Mbi215 and Mru03 & 0.18 & Mbi233 and Tc4.287 & 0.94 \\
Mbi218 and Mru03 & 0.71 & Mbi254 and Tc4.287 & 0.49 \\
Mbi232 and Mru03 & 0.85 & Mbi256 and Tc4.287 & 0.98 \\
Mbi233 and Mru03 & 1.00 & Mru03 and Tc4.287 & 0.98 \\
Mbi254 and Mru03 & 1.00 & Mru14 and Tc4.287 & $0.04 *$ \\
Mbi256 and Mru03 & 0.99 & Mmo15 and Tc4.287 & 0.60 \\
Mbi215 and Mru14 & 0.95 & & 0.69 \\
Mbi218 and Mru14 & 0.41 & & \\
\hline
\end{tabular}

*Significant after sequential Bonferroni's correction $(\mathrm{P} \leq 0.05)$. For locus abbreviations, see Table 2. 
Table 6. Values of pairwise $F_{\mathrm{ST}}$ in samples of Melipona scutellaris from Recôncavo Baiano.

\begin{tabular}{|c|c|c|c|c|c|c|c|c|c|c|c|}
\hline$F_{\mathrm{ST}}$ & $\mathrm{AM}$ & CBP & $\mathrm{CF}$ & $\mathrm{CA}$ & $\mathrm{DMC}$ & GOV & JG & JQ & MGJ & SF & VC \\
\hline$\overline{\mathrm{AM}}$ & 0 & & & & & & & & & & \\
\hline CBP & $0.05^{\mathrm{NS}}$ & 0 & & & & & & & & & \\
\hline $\mathrm{CF}$ & $0.07^{\mathrm{NS}}$ & $0.07^{\mathrm{NS}}$ & 0 & & & & & & & & \\
\hline $\mathrm{CA}$ & 0.00 & $0.06^{\mathrm{NS}}$ & $0.10^{\mathrm{NS}}$ & 0 & & & & & & & \\
\hline DMC & -0.01 & $0.10^{\mathrm{NS}}$ & 0.06 & -0.01 & 0 & & & & & & \\
\hline GOV & $0.11^{*}$ & $0.19^{*}$ & $0.20^{*}$ & $0.09 *$ & $0.09^{*}$ & 0 & & & & & \\
\hline JG & $0.08^{*}$ & $0.12 *$ & 0.03 & $0.07 *$ & 0.03 & $0.15^{*}$ & 0 & & & & \\
\hline JQ & $0.12 *$ & $0.19^{*}$ & $0.18^{\mathrm{NS}}$ & $0.17^{*}$ & $0.15^{*}$ & $0.13^{*}$ & $0.18^{*}$ & 0 & & & \\
\hline MGJ & $0.14^{*}$ & $0.15^{*}$ & $0.16^{*}$ & $0.13^{*}$ & $0.10^{\mathrm{NS}}$ & $0.18^{*}$ & $0.12^{*}$ & $0.23 *$ & 0 & & \\
\hline SF & $0.10^{*}$ & $0.12^{*}$ & $0.13^{*}$ & $0.09^{*}$ & $0.06^{\mathrm{NS}}$ & $0.15^{*}$ & $0.09^{*}$ & $0.22 *$ & $0.10^{*}$ & 0 & \\
\hline $\mathrm{VC}$ & $0.06^{*}$ & $0.12^{*}$ & $0.16^{*}$ & $0.05^{*}$ & $0.01^{\mathrm{NS}}$ & $0.14^{*}$ & $0.08^{*}$ & $0.20 *$ & $0.07 *$ & $0.08 *$ & 0 \\
\hline
\end{tabular}

*Significant after sequential Bonferroni's correction $(\mathrm{P} \leq 0.05)$. ${ }^{\text {NS}}$ Non-significant after sequential Bonferroni's correction $(\mathrm{P} \leq 0.05)$. For locality abbreviations, see Table 1.

Table 7. Analysis of molecular variance (AMOVA) and fixation index $\left(F_{\mathrm{ST}}\right)$ values obtained in all microsatellite loci analyzed of Melipona scutellaris from Recôncavo Baiano.

\begin{tabular}{lcc}
\hline Source of variation & Components of variance & Percentage variation \\
\hline Among populations & 0.28 & 10.67 \\
Within populations & 2.41 & 89.33 \\
Total & 2.70 & \\
$F_{\mathrm{ST}}$ & 0.10 & \\
\hline
\end{tabular}

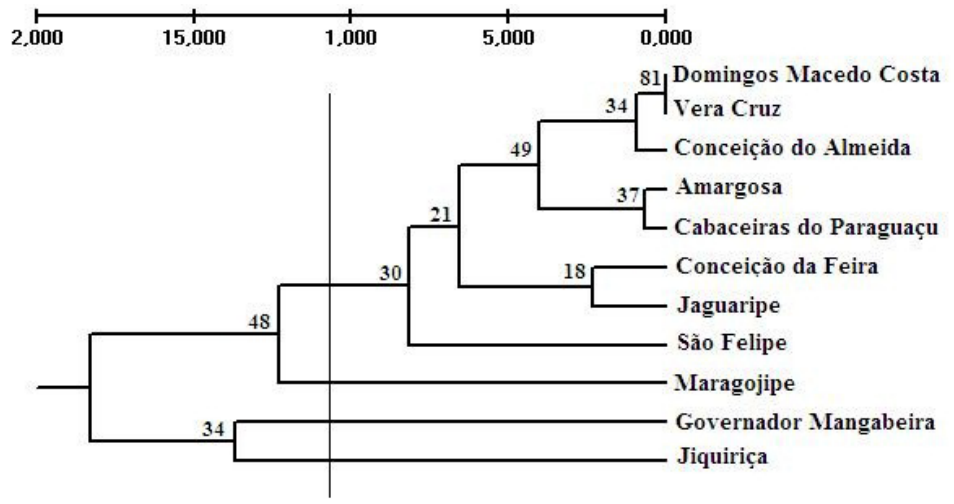

Figure 2. UPGMA dendrogram showing the mean genetic distances among the sampled localities of Melipona scutellaris.

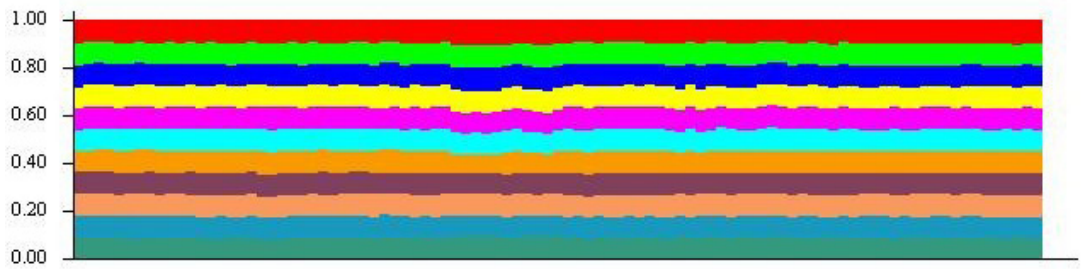

Figure 3. Graph of Bayesian analysis using the Structure software showing no genetic structure in Melipona scutellaris samples. 


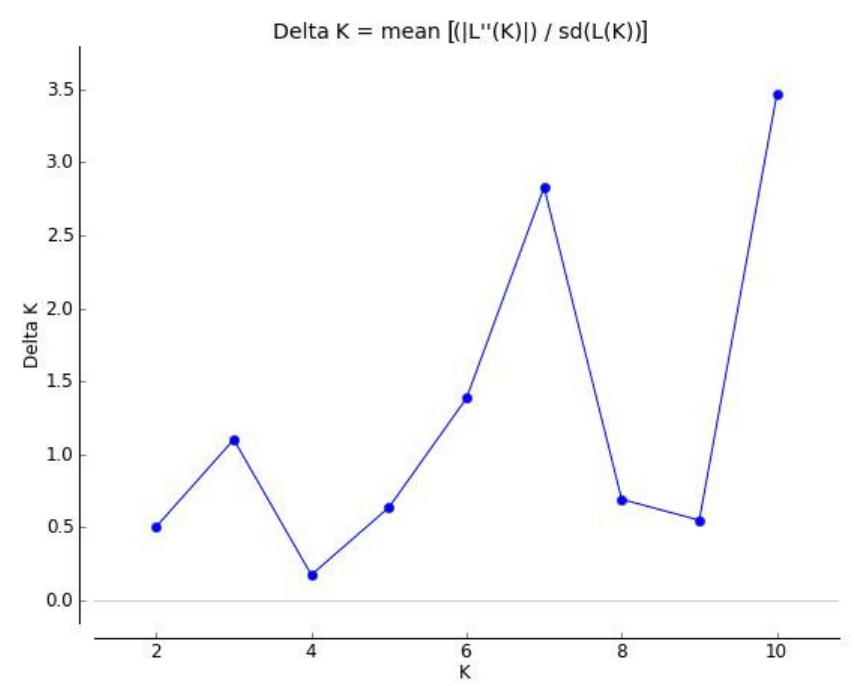

Figure 4. Graph showing the $\mathrm{K}$ values based on the genetic data of Melipona scutellaris samples using the Harvester software.

\section{DISCUSSION}

The number of alleles varied in the M. scutellaris samples, as reported previously by Peters et al. (1998) in M. bicolor. The number of alleles per locus and $H_{\mathrm{O}}$ observed in $M$. bicolor ranged from 3 to 6 and from 0.12 to 0.88 , respectively. When the primers Mbi were tested in M. quadrifasciata, the number of alleles per locus ranged from 1 to 4 and the $H_{\mathrm{O}}$ varied from 0 to 1 . Once these primers are heterologous, the amplified regions might be different either in size or base pair composition from the sequences in M. bicolor, thus amplifying distinct loci (Carvalho-Zilse and Kerr, 2006). Besides, mutations in the flanking regions might hinder the annealing of primers to template DNA during amplification via PCR, resulting in a null allele (Chapuis and Estoup, 2007), differently from the results in the present study once null alleles were corrected for.

Variation in $H_{\mathrm{O}}$ and $H_{\mathrm{E}}$ was also observed by Lopes et al. (2009) in M. rufiventris and by Green et al. (2001) in Trigona carbonaria. A significant deviation from HWE was detected when loci Mru03 and Tc4.287 were compared after sequential Bonferroni's correction. The loci Mbi215, Mru03, Mru14, Mmo15, and Tc4.287 were not in proportion to HWE in some localities. The deviation from HWE and the lack of these data in some loci are likely to be caused by the low frequency or absence of heterozygotes in these populations. The small sample size of certain localities, e.g., CF and SF (4 sampled colonies each), CBP and DMC (5 colonies each), and JQ (6 colonies each), might have limited the detection of polymorphisms in these populations. It should be pointed out that low levels of sampling are related to the decreased population size of M. scutellaris in the studied region, which also justifies the development of similar studies that might be helpful for the preservation and conservation management of this species.

Another putative explanation for the low frequency of heterozygotes in Melipona refers to the swarming behavior of these bees, preferential mating with a single male, and 
presence of a single active physogastric queen bee per colony. In Melipona, the establishment of new nests is dependent on the mother colony, which results in reduced migration distances within similar environments (Kerr, 1987). Moreover, some studies have shown that the utilization of heterologous primers, although being useful to assess the genetic structure in other species, might lead to lower polymorphism levels than species-specific microsatellite primers (Francisco et al., 2006).

Even though the pairwise $F_{\mathrm{ST}}$ comparisons were statistically significant, the values obtained are considered low for meliponins inasmuch as this index was also low when all samples were grouped, revealing little genetic structure among the studied populations of M. scutellaris. Furthermore, the UPGMA and Bayesian analysis (using Structure) showed a lack of structuring among these populations. AMOVA showed that $89.32 \%$ of the overall genetic variation in this species was found within localities and only $10.67 \%$ was found among them, thus corroborating the absence of genetic structure in these samples.

In spite of the $\mathrm{K}=10$ obtained in Harvester, the graph and $\mathrm{Q}$ values generated using Structure indicate no genetic structure. According to Pritchard et al. (2000), even when genetic structure is absent, the $\mathrm{K}$ values might be higher than 1 when a species undergoes high inbreeding rates.

The results obtained by grouping analyses (UPGMA) and Bayesian inference can be related to the low polymorphic nature of the loci analyzed, commercialization and trade of swarms by bee keepers, changes in larval disks, rational multiplication of colonies, deforestation, and destruction of nesting sites leading to the admixture of genetic material, and the reduction of natural colonies, thus hindering population analysis in M. scutellaris. In fact, M. scutellaris is the most commercially raised stingless bee species that, if not managed properly, might undergo decreased levels of genetic variation.

Nonetheless, population genetic studies allow the development of efficient management strategies that are able to maintain the genetic variation of populations and to minimize the effects of inbreeding and the loss of alleles. It has been well established that decreased genetic variation as a consequence of inbreeding and allele loss reduces the ability of populations to adapt to environmental changes and, therefore, hinders their long-term survival (Arif and Khan, 2009).

\section{ACKNOWLEDGMENTS}

The authors are grateful to the bee keepers that kindly provided the samples of Melipona scutellaris, to Programa Nacional de Pós-Doutorado (PNPD), Coordenação de Aperfeiçoamento de Nível Superior (CAPES), Fundação de Amparo à Pesquisa do Estado da Bahia (FAPESB), UFRB (Universidade Federal do Recôncavo da Bahia), and UESB (Universidade Estadual do Sudoeste da Bahia) for financial support.

\section{REFERENCES}

Arif IA and Khan HA (2009). Molecular markers for biodiversity analysis of wildlife animals: a brief review. Anim. Biodivers. Conserv. 32: 9-17.

Carvalho-Zilse GA and Kerr WE (2006). Utilização de marcadores microssatélites para estudos populacionais em Melipona scutellaris (Apidae, Meliponini). Magistra 18: 213-220.

Chapuis MP and Estoup A (2007). Microsatellites null alleles and estimation of population differentiation. Mol. Biol. Evol. 24: 621-631. 
Dias LAS (1998). Análises Multidimensionais. In: Eletroforese de Isoenzimas e Proteínas Afins: Fundamentos e Aplicações em Plantas e Microrganismos (Alfenas AC, ed.). Viçosa, UFV, 405-475.

Earl DA and vonHoldt BM (2012). STRUCTURE HARVESTER: a website and program for visualizing STRUCTURE output and implementing the Evanno method. Conserv. Genet. Resour. 4: 359-361.

Excoffier L, Laval G and Schneider S (2005). Arlequin (version 3.0): An integrated software package for population genetics data analysis. Evol. Bioinform. Evol. Bioinformatics Online 1: 47-50.

Francisco FO, Brito RM and Arias MC (2006). Alelle number and heterozigosity for microssatellite loci in different stingless bee species (Hymnoptera: Apidea, Meliponini). Neotrop. Entomol. 35: 638-643.

Goudet J (1995). FSTAT (version 1.2): a computer program to calculate F-statistics. J. Hered. 86: 485-486.

Green CL, Franck P and Oldroyd BP (2001). Characterization of microsatellite loci for Trigona carbonaria, a stingless bee endemic to Australia. Mol. Ecol. Notes 1: 89-92.

Kerr WE (1987). Abelhas indígenas brasileiras (meliponíneos) na polinização e na produção de mel, pólen, geoprópolis e cera. Informe Agropecuário 13: 15-22.

Kerr WE, Almeida GA and Nascimento VA (1996). Abelha Urucu: Biologia, Manejo e Conservação. Fundação Acangaú, Belo Horizonte, 141.

Lopes DM, DA Silva FO, Fernandes Salomão TM, Campos LA, et al. (2009). Microsatellite loci for the stingless bee Melipona rufiventris (Hymenoptera: Apidae). Mol. Ecol. Resour. 9: 923-925.

Miller MP (1997). Tools for population genetic analyses (TFPGA) 1.3: A Windows program for the analysis of allozyme and molecular population genetic data. Available at [http://www.marksgeneticsoftware.net/tfpga.htm].

Nei M (1978). Estimation of average heterozygosity and genetic distance from a small number of individuals. Genetics 89: $583-590$.

Oliveira AP and Albuquerque CL (2010). Um Panorama do Recôncavo Baiano: Sociedade, Economia e Cultura. Available at [http://www.narradoresdoreconcavo.com.br/index/reconcavo]. Accessed July 12, 2012.

Peters JM, Queller DC, Imperatriz-Fonseca VL and Strassmann JE (1998). Microsatellite loci for stingless bees. Mol. Ecol. 7: 783-792.

Petit RJ, El Mousadik A and Pons O (1998). Identifying populations for conservation on the basis of genetic markers. Conserv. Biol. 12: 844-855.

Pritchard JK, Matthew S and Donnelly P (2000). Inference of population structure using multilocus genotype data. Genetics 155: 945-959.

Raymond ML and Rousset F (1995). An exact test for population differentiation. Evolution 49: 1280-1283.

Rice WR (1989). Analysing tables of statistical tests. Evolution 43: 223-225.

Waldschmidt AM, Salomão TMF, Barros EG and Campos LAO (1997). Extraction of genomic DNA from Melipona quadrifasciata (Hymenoptera: Apidae, Meliponinae). Rev. Bras. Genet. 20: 421-423.

Weir BS and Cockerham CC (1984). Estimating F-statistics for the analysis of population structure. Evolution 38: 13581370 . 